Наведено дослідження впливу термічного і радіаційного чинників на елементний склад $i$ фазово-структурний стан іонно-плазмових конденсатів WC-TiC квазібінарних системи. В якості термічного фактора в роботі використовувалася різна температура підкладки при осадженні та температура високотемпературних відпалов покриттів після їх осадження. Вплив радіаційного фактора змінювалося шляхом подачі різного за величиною негативного потенціалу зміщення на підкладку в процесі осадження покриття.

Встановлено, що зі зміною температури підкладки при осадженні (в інтервалі температур $80-950{ }^{\circ} \mathrm{C}$ ) відбувається зміна в елементному складі покриття. Зі збільиенням температури осадження підвишується відносний вміст важких металевих атомів Wi зменшується відносний вміст атомів Ті і С. На фазово-структурному рівні це призводить до зміни від однофазного стану ((W, Ti) C пересичений твердий розчин при температурі осадження менше за $\left.700{ }^{\circ} \mathrm{C}\right)$ до двофазного ((W, Ti) $\mathrm{C} i \alpha-W_{2} C$ фази при температурі осадження більи за $\left.700{ }^{\circ} \mathrm{C}\right)$. Використання високотемпературних відпалов покриттів після їх формування показало порівняно низъку ефективність активації розпаду. При температурі відпалу $800{ }^{\circ} \mathrm{C}$ помітної зміни фазово-структурного стану не спостерігається, а при найбільи високій температурі $1000{ }^{\circ} \mathrm{C}$ і витримці протягом 2-x годин вміст $\alpha-W_{2} C$ фази відносно мале $і$ не перевищує 15 об \%. Подача потениіалу зсуву стимулює утворення двухфазного стану 3 (W, Ti) $\mathrm{C} i \alpha-W_{2} C$ фаз з нанометровим розміром кристалітів. Зі збільшенням потенціалу зсуву від -50 В до -115 В середній розмір кристалітів зменшуеться віӘ 4.5 нм до 3.8 нм.

Використання в роботі методів структурної інженерії для створення двофазних матеріалів на основі квазібінарної WC-TiC системи є основою для підвищення мічності і тріщиностійкості покриттів таких систем

Ключові слова: квазібінарна система, елементний склад, температура підкладки, потенціал зсуву, пересичений твердий розчин

Received date 22.08.2019

Accepted date 07.10.2019

Published date 31.10.2019
UDC $539.216 .2 ; 539.26$

DOI: $10.15587 / 1729-4061.2019 .181291$

\title{
A STUDY OF THE EFFECT OF DEPOSITION CONDITIONS ON THE PHASE-STRUCTURAL STATE OF ION-PLASMA WC - TIC COATINGS
}

\author{
O. Sobol \\ Doctor of Physical and Mathematical Sciences, \\ Professor \\ Department of Materials Science \\ National Technical University "Kharkiv \\ Polytechnic Institute" \\ Kyrpychova str., 2, Kharkiv, Ukraine, 61002 \\ E-mail: sool@kpi.kharkov.ua \\ O s m a n D r \\ Researcher \\ Hacettepe University Technopolis \\ Üniversiteler Mahallesi, 1596, Cadde 6. F-Blok \\ Kat:3 Beytepe, Ankara, Turkey, 06800 \\ Copyright (C) 2019, O. Sobol, Osman Dur \\ This is an open access article under the CC BY license \\ (http://creativecommons.org/licenses/by/4.0)
}

\section{Introduction}

In recent years, structural engineering has been the main method for creating materials with the necessary functional characteristics [1,2]. Of particular importance is the method of structural engineering (that is, the establishment of regularities of structural states depending on the parameters of obtaining the material [3]) due to the use of highly nonequilibrium methods of forming materials $[4,5]$. Among these methods is the preparation of coatings from ion-plasma flows [6,7]. As a result, it was possible to expand the areas of temperature and concentration stabilization of phase-structural states $[8,9]$. This allowed us to create new types of materials with high functional properties $[10,11]$. The highest mechanical properties were achieved for systems including silicon $[12,13]$. The second feature of these coatings was the nanoscale structure of constituent elements $[14,15]$. Such a structural state was called a nanocomposite [16]. Subsequently, nanocomposites (i. e., composites based on nanosized elements) were creatr ed on the basis of two structural approaches [17,18]. The first approach is by stratification of the supersaturated solid solutions into several phases (mainly by spinodal-like mechanisms) $[19,20]$. The second approach is through the creation of multilayer composite materials with nanometer layer thick- ness [21,22]. Common to these approaches is that the basis for achieving high physical and mechanical characteristics is largely determined by the properties of the interphase boundary (grain adhesion [23], elastic characteristics [24], the ability to relax stresses [6], block crack propagation [25], etc.).

Therefore, the creation of nanocomposites based on the decomposition of supersaturated solid solutions of quasibinary systems with the formation of high-strength intergranular boundaries is the basis for achieving unique properties. However, with an increase in the number of components, the calculation of parameters when modeling such structures is very complicated and is rarely used in practice. For quasibinary systems, such calculations are complicated by the multilevel hierarchy of the formation process (associated with the possibility of forming a supersaturated solid solution as a transition state). And in this regard, the use of a structural approach based on the systematization of empirical data is becoming increasingly relevant.

\section{Literature review and problem statement}

Nanocomposite coatings are the basis of most modern technologies [26, 27]. The preparation of such coatings by the PVD 
(physical vacuum deposition) method in most cases takes place under highly nonequilibrium conditions [28]. In this case, a nanostructural state is formed in the coatings themselves [29]. For such nonequilibrium systems, phase diagrams differ significantly from equilibrium ones. Changes in state diagrams are due, first of all, to an increase in the mutual solubility of elements in a nanostructured state. This, in particular, leads to a significant expansion of the solubility boundaries of solid solutions [30]. When the necessary conditions are created, structural restructuring of such a system takes place to reduce its nonequilibrium [31]. Under such conditions, the FCC crystal lattice (structural type of $\mathrm{NaCl}$ ) is the most sTable for the interstitial phases based on transition metals $[6,13]$. This stap bility is due to the ability of such a structure in the formation of "empty" octahedra in the crystal lattice (that is, for example, for carbides - carbon vacancies) to counteract the stresses caused by $\mathrm{Me}-\mathrm{Me}$ bonds [32]. The limiting concentration of carbon vacancies that such a structure "withstands" depends on the ratio of the strength of the $\mathrm{Me}-\mathrm{C}$ bond and the $\mathrm{Me}-\mathrm{Me}$ bond (Me is a transition metal, $\mathrm{C}$ is carbon).

To assess the bond strength, the enthalpy of formation is used [33, 34]. According to the data from [33, 34], dependences of the enthalpy of formation of carbides and borides for the most promising (in the order of increasing their atomic number) metals of the transition group are constructed in Fig. 1.

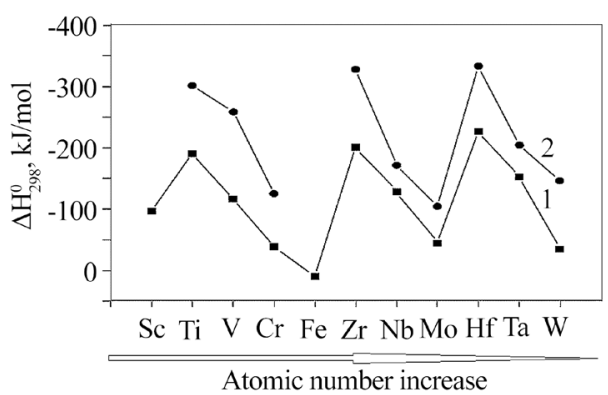

Fig. 1. Dependence of the formation enthalpy on the type of metal component in carbides and borides:

$1-\mathrm{MeC}$ type carbide, $2-\mathrm{MeB}_{2}$ type boride

It can be seen from Fig. 1 that a decrease in the statistical weight of sTable $\mathrm{d}^{5}$-electronic configurations (upon transition from VI metals to group IV metals) leads to a significant increase in the $\mathrm{Me}-\mathrm{C}$ interaction. This leads to greater stability of the structure to displacements of metal atoms when carbon vacancies appear.

Thus, the combination of metal carbides of the IVth (TiC) and VIth group (WC) into the quasibinary system WC-TiC allows us to obtain a unique combination of components with strong $\mathrm{Me}-\mathrm{C}$ (for $\mathrm{TiC}$ ) and $\mathrm{Me}-\mathrm{Me}$ (for $\mathrm{WC}$ ) bonds. In this case, the phase and structural state of such systems should be strongly influenced by thermal and radiation factors. This determines the great need for obtaining and processing systematized empirical data on the influence of thermal and radiation factors on the elemental composition and phase-structural state of ion-plasma condensates of the WC-TiC quasibinary system.

\section{The aim and objectives of the study}

The aim of the study is to establish the laws governing the influence of thermal and radiation factors on the elemental composition and phase-structural state of ion-plas- ma (DC planar magnetron) coatings of the quasibinary WC-TiC system.

To achieve the goal, the following objectives were set:

- to study the effect of substrate temperature during deposition on the elemental composition and phase-structural state of ion-plasma condensates;

- to determine the possibility of decomposition of a solid solution with the formation of a two-phase state by high-temperature annealing of coatings after their formation;

- to establish the effect of supplying a negative bias potential to the substrate during deposition on the phase-structural state of the coatings of a quasibinary WC-TiC system.

\section{Materials and methods for the preparation and study of coatings of the quasibinary WC-TiC system}

Coatings were obtained by ion sputtering of the target cathode. For sputtering, a planar magnetron circuit was used.

Targets for spraying were made by hot pressing at a temperature $T_{h p} \approx 1700^{\circ} \mathrm{C}$. The targets were biphasic and contained $\mathrm{TiC}$ phases with a cubic lattice of structural type $\mathrm{NaCl}$ and a WC phase with a simple hexagonal lattice. Targets of $90 \mathrm{~mol} \% \mathrm{WC}-10 \mathrm{~mol} \%$ TiC composition were used.

Spraying was carried out in an inert gas Ar at a pressure of $0.2-0.3 \mathrm{~Pa}$. The applied spray voltage of $320 \ldots 400 \mathrm{~V}$ ensured the flux density of the deposited metal atoms $j_{\mathrm{Me}} \approx(2 \ldots 9) 10^{15} \mathrm{~cm}^{-2} \mathrm{~s}^{-1}$

As a thermal factor, we used different substrate temperatures during deposition and temperatures of high-temperature annealing of coatings after their deposition. The deposition temperature $\left(T_{s}\right)$ was varied in the range of 80 $950{ }^{\circ} \mathrm{C}$ by controlled heating of a specially designed Table for samples. Annealing was carried out in a vacuum of $10^{-5} \mathrm{~Pa}$ at temperatures of $800{ }^{\circ} \mathrm{C}$ and $1000{ }^{\circ} \mathrm{C}$.

The influence of the radiation factor was changed by applying a negative bias potential of different magnitudes to the substrate during coating deposition. For this, 3 modes were used during deposition: without applying a negative potential, and also when applying a potential of $-50 \mathrm{~V}$ and $-115 \mathrm{~V}$.

The coating thickness was $1.2-1.7 \mu \mathrm{m}$. As substrates, polished single crystal silicon wafers were used.

To study the phase-structural state, the X-ray diffraction method was used. Diffraction spectra were obtained on a DRON-4 setup in $\mathrm{Cu}-\mathrm{K}_{\alpha}$ radiation (wavelength $0.154 \mathrm{~nm}$ ). At the same time, the Bragg-Brentano survey scheme was used. To monochromatize the detected radiation, we used a graphite monochromator, which was installed in the secondary beam (in front of the detector) [35]. The angular range of the survey was $25-85^{\circ}$ with a scan step of $0.01^{\circ}$. The exposure time at the point was $20 \ldots 100 \mathrm{~s}$. To decode the diffraction spectra, tables of the Powder Diffraction File international center for diffraction data were used [36]. The crystallite size was determined by changing the width of the diffraction peaks [37].

Electron microscopy studies were carried out using a JEOL - 2100 transmission electron microscope (JEOL Ltd., Japan) and a FEI Nova NanoSEM 450 scanning electron microscope (FEI, USA). The elemental composition of the coatings was studied by analyzing the spectra of characteristic X-ray radiation generated by an electron beam in a scanning electron microscope. 
5. Results of a study of the influence of the thermal factor on the phase-structural state of WC-TiC condensates

The main studies were carried out for coatings obtained by sputtering a target with a composition of $10 \mathrm{~mol}$. \% TiC 90 mol. \% WC. The choice of this composition as the base was due to two factors. The first factor is that the ratio close to $1 / 9$ in nanocomposites (the formation of which passes by the spinodal decomposition mechanism) according to experimental studies is optimal for obtaining high functional properties $[38,39]$. The second factor is that, as shown by previous studies [18], for quasibinary systems with such a content of basic components, a two-phase structural state of the nanocomposite is formed, which allows one to study the effect of interfacial interaction on structural engineering.

Initially, a study of the thermal factor was carried out. In this case, the main technological parameter of the effect on the structural state was the temperature value $T_{s}$. The base temperature $T_{s}$ in the study of the structure and properties of the coatings was chosen $T_{s}=700^{\circ} \mathrm{C}$. This is due to the highest functional characteristics revealed for such $T_{s}$ for a quasibii nary diboride system similar in decay mechanism [18].

Fig. 2 presents raster electron microscopic images of the side surface of the coating obtained at $T_{s}=700{ }^{\circ} \mathrm{C}$, as well as maps of the distribution of elements by their thickness.

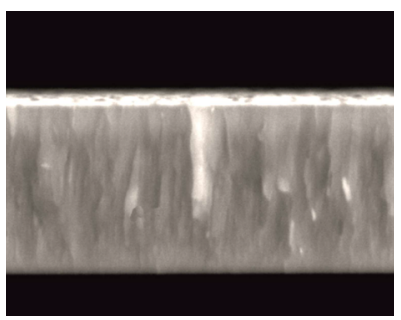

$a$

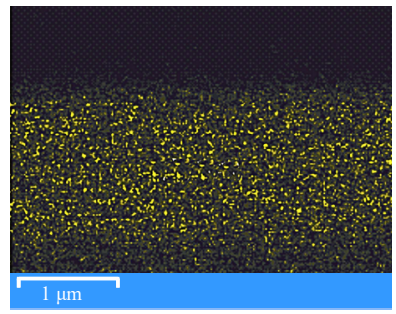

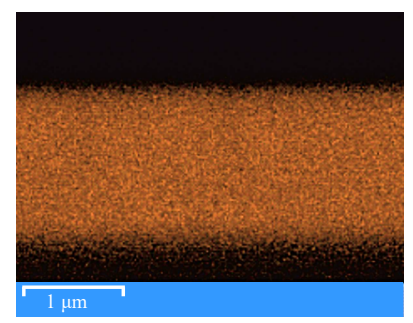

$b$

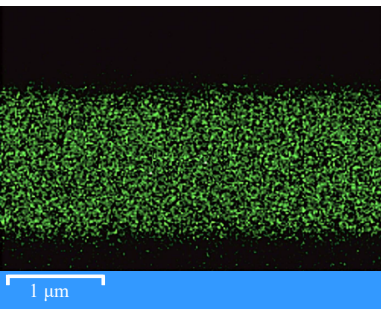

$d$
Fig. 2. View of the side surface of the coating obtained at $T_{s}=700{ }^{\circ} \mathrm{C}$ and the distribution map of the elements: $a$ - side surface; $b$ - distribution of W;

$\mathrm{c}-$ distribution of Ti; $d$-distribution of $\mathrm{C}$

One can see a fairly uniform distribution of $\mathrm{W}$ and $\mathrm{C}$ atoms in the coating volume and the formation of inhomogeneity sites as a result of depletion of Ti atoms. The grains themselves have a columnar shape. In accordance with the Thornton model [40], such a structure is characteristic of the relatively low mobility of the deposited atoms and is determined in this case by the main metal atoms - heavy tungsten atoms [24]. The inhomogeneous distribution of $\mathrm{Ti}$ atoms over the coating volume is associated with its relatively low content.

To determine the elemental composition, the method of energy dispersive analysis was used. Fig. 3 shows the characteristic energy dispersive spectrum of the coating obtained at $T_{S}=700^{\circ} \mathrm{C}$. It can be seen that the spectrum contains peaks from the main elements $\mathrm{W}, \mathrm{Ti}$, and $\mathrm{C}$ in different energy ranges. Based on these data, the elemental composition was calculated programmatically.

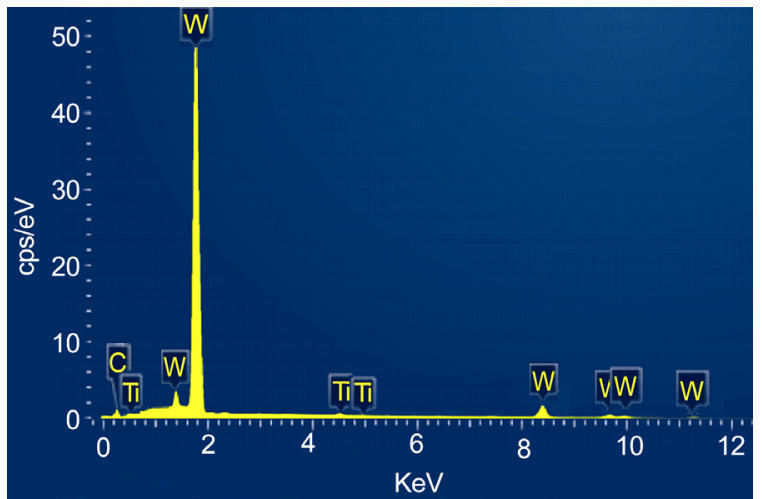

Fig. 3. Energy dispersive spectrum of the coating deposited at $T_{s}=700{ }^{\circ} \mathrm{C}$

Table 1 shows the results of determining the elemental composition for 3 types of coatings obtained with different $T_{s}$. Table 1 shows that compared with the target, the coatings are enriched with heavy tungsten atoms. The reason for such a difference may be secondary selective sputtering of lighter $\mathrm{Ti}$ and $\mathrm{C}$ atoms from the deposited surface. With increasing condensation temperature, the intensity of secondary sputtering increases, which is manifested in a change in the $\mathrm{Ti} / \mathrm{W}$ atomic ratio in the coatings relative to the target. Along with the change in $\mathrm{Ti} / \mathrm{W}$ in the coatings, the carbon content also changes. However, in this case, another dependence is observed: the relative content of $\mathrm{C}$ atoms in the coatings increases with increasing Ti content. The observed trend can be associated with a significantly higher heat of formation of titanium carbide compared with tungsten carbide $(-183.8 \mathrm{~kJ} / \mathrm{mol}$ and $-37.7 \mathrm{~kJ} / \mathrm{mol}$, respectively). On the one hand, this determines the greater stability of TiC under thermal action, and on the other, justifies the model of preferential atomization of atoms directly from the coating formation surface.

Table 1

Composition of the coatings deposited at different $T_{S}$ upon sputtering a target with a composition of 90 mol. \% WC - $10 \mathrm{~mol}$ \% TiC

\begin{tabular}{|c|c|c|c|}
\hline \multirow{2}{*}{$T_{S},{ }^{\circ} \mathrm{C}$} & \multicolumn{3}{|c|}{ Composition of the coatings, at. \% } \\
\cline { 2 - 4 } & $\mathrm{Ti}$ & $\mathrm{W}$ & $\mathrm{C}$ \\
\hline 300 & 8.4 & 50.3 & 41.3 \\
\hline 700 & 6.1 & 56.1 & 37.8 \\
\hline 950 & 5.3 & 60.2 & 34.5 \\
\hline
\end{tabular}

To determine the phase-structural state, the XRD method was used. Fig. 4 shows the diffraction spectra from coatings obtained at different $T_{s}$. As can be seen from Fig. 4, at the lowest $T_{S}=80^{\circ} \mathrm{C}$, a single-phase state of the (W, Ti)C solid solution is formed upon condensation on the basis of the FCC crystal lattice (structural type $\mathrm{NaCl}$ ). According to the Powder Diffraction File card file [36], this type of structure corresponds to the PDF card 20-1316. The structure of such a coating is polycrystalline without the preferred orientation of crystallites. An increase in $T_{s}$ to $300^{\circ} \mathrm{C}$ leads to the appearance of a predominant orientation of crystallites with the [100] axis perpendicular to the growth plane (the texture 
appears on the diffraction spectrum in an increase in the relative intensity of the peak (200)).

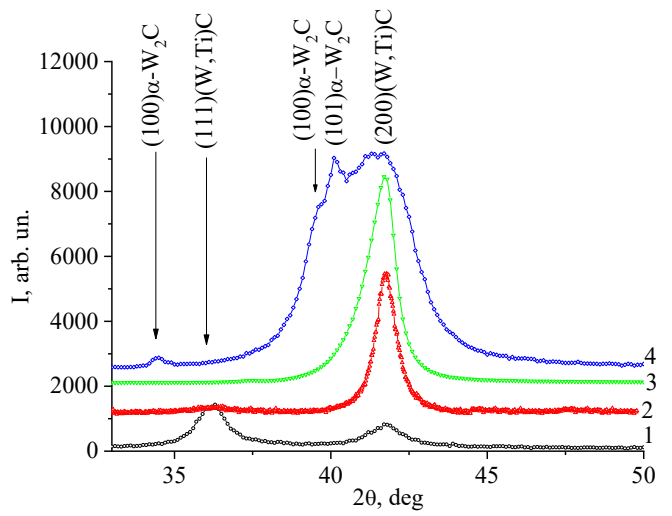

Fig. 4. X-ray diffraction patterns of coatings deposited at different $T_{s}: 1-80{ }^{\circ} \mathrm{C}, 2-300{ }^{\circ} \mathrm{C}, 3-700{ }^{\circ} \mathrm{C}, 4-950{ }^{\circ} \mathrm{C}$

The crystallite size in the coatings was $11-14 \mathrm{~nm}$. For the coating obtained at $T_{s}=700{ }^{\circ} \mathrm{C}$ (spectrum 3 in Fig. 4), the diffraction profile becomes asymmetric, which indicates the appearance of diffraction peaks from crystallites with a different type of crystal lattice. These peaks are more pronounced in the diffraction spectrum of the coating obtained at $T_{s}=950{ }^{\circ} \mathrm{C}$ (spectrum 4 in Fig. 4). According to the card index data [36], the second type of structure corresponds to the $\alpha-\mathrm{W}_{2} \mathrm{C}$ phase (PDF card 35-0776).

To determine the stability of the pre-precipitation state in the coating obtained at $T_{s}=700{ }^{\circ} \mathrm{C}$, it was vacuum anf nealed at a temperature of $1000^{\circ} \mathrm{C}$ for 2 hours. As can be seen from the obtained diffraction comparison spectra (Fig. 5) during annealing, the decomposition of a solid solution leads to the formation of a two-phase state from (W, Ti) $\mathrm{C}$ and $\alpha-\mathrm{W}_{2} \mathrm{C}$ phases.

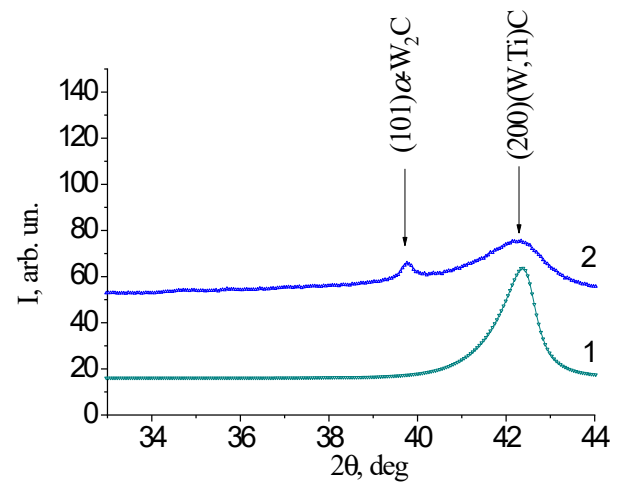

Fig. 5. X-ray diffraction patterns of coatings $\left(T_{s}=700{ }^{\circ} \mathrm{C}\right)$ obtained by sputtering a target of

10 mol. \% TiC -90 mol. \% WC: 1 - before annealing, 2 - after 2 hours annealing at $1000{ }^{\circ} \mathrm{C}$

In this case, the diffraction profile of the (200) (W, Ti) $\mathrm{C}$ peak broadens after annealing. Before annealing, the peak width at half maximum was $0.96^{\circ}$ (spectrum 1), and after annealing, it was $1.42^{\circ}$ (spectrum 2). This indicates the dispersion of crystallites and the development of high microdeformation. To determine the volume content of the $\alpha-\mathrm{W}_{2} \mathrm{C}$ phase, the basic X-ray diffraction analysis technique was used based on the values of the integrated area of diffraction lines and the reflectivity of the corresponding plane. As a percentage, the volume of the isolated $\alpha-W_{2} C$ phase was $15 \%$.

\section{Results of a study of the influence of the radiation factor on the phase-structural state of WC-TiC condensates}

When studying the influence of the radiation factor, the main parameter of the effect was the negative bias potential applied to the substrate during the deposition process. To study the phase-structural state of condensates, the XRD method was used. The generalized data of the XRD spectra of the coatings obtained at $T_{s}=700{ }^{\circ} \mathrm{C}$ and different bias poe tentials on the substrate are shown in Fig. 6.

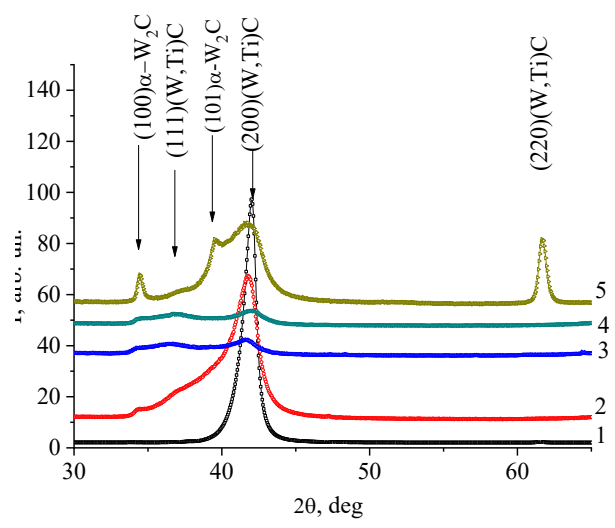

Fig. 6. X-ray diffraction patterns of coatings deposited at $T_{s}=700^{\circ} \mathrm{C}: 1-$ without a bias potential, $2-$ with a bias potential $-50 \mathrm{~V}, 3-$ with a bias potential $-115 \mathrm{~V}, 4-$ with a bias potential $-115 \mathrm{~V}$ and annealing at $800{ }^{\circ} \mathrm{C}$ for 1 hour, $5-$ at $T_{s}=950{ }^{\circ} \mathrm{C}$ without bias potential

It is seen that an increase in the energy of the deposited particles (when applying the bias potential) is accompanied by an increase in the decomposition of the solid solution and the formation of a two-phase condensate. In this case, in the diffraction spectra, with an increase in the bias potential, the relative intensity of the peak (200) (W, Ti)C decreases and the asymmetry of the diffraction profile increases from the side of smaller angles (Fig. 6, spectra 1 and 2). The supply of the highest displacement potential of $-115 \mathrm{~V}$ leads to a strong disorientation of crystallites and the absence of texture. However, due to the imposition of several diffraction lines, their analysis is possible only after decomposition of a complex profile.

Fig. 7 shows the results of decomposition with the allocation of diffraction peaks from two phases.

Fig. 7, $a$ shows that the supply of a $-50 \mathrm{~V}$ bias potential during deposition leads to an increase in the width of diffraction peaks (which corresponds to a decrease in the size of crystallites of the (W, Ti)C phase to $4.5 \mathrm{~nm}$ ). In this case, the preferred orientation of growth with the [100] axis of crystallites of the $(\mathrm{W}, \mathrm{Ti}) \mathrm{C}$ phase is retained. Crystallites of the $\alpha-\mathrm{W}_{2} \mathrm{C}$ phase also have an average size of about $4 \mathrm{~nm}$. The volume content of the $\alpha-W_{2} C$ phase is about $25 \%$.

The potential supply of $-115 \mathrm{~V}$ during deposition is accompanied by the appearance of the texture of the [111] ( $\mathrm{W}, \mathrm{Ti}) \mathrm{C}$ phase and a decrease in the average crystallite size to $3.8 \mathrm{~nm}$. As can be seen from Fig. 6, annealing of such a coating for 1 hour at a temperature of $800^{\circ} \mathrm{C}$ does not lead to structural changes, but is accompanied by a shift of the peak toward large angles, which may be due to relaxation of the initial compression stresses in the coating.

A similar effect of the decomposition of a solid solution with the formation of a two-phase state is also manifested at 
a higher coating deposition temperature $T_{s}=950{ }^{\circ} \mathrm{C}$ (Fig. 6 , spectrum 5). However, as can be seen from the decomposition of this profile (Fig. 7, c), in this case only the crystallites of the $(\mathrm{W}, \mathrm{Ti}) \mathrm{C}$ phase are strongly crushed (the average size decreases to $3.2 \mathrm{~nm}$ ). The average crystallite size of the $\alpha-W_{2} C$ phase is much larger and is about $10 \mathrm{~nm}$. The volume content of the $\alpha-W_{2} C$ phase is about $30 \%$.
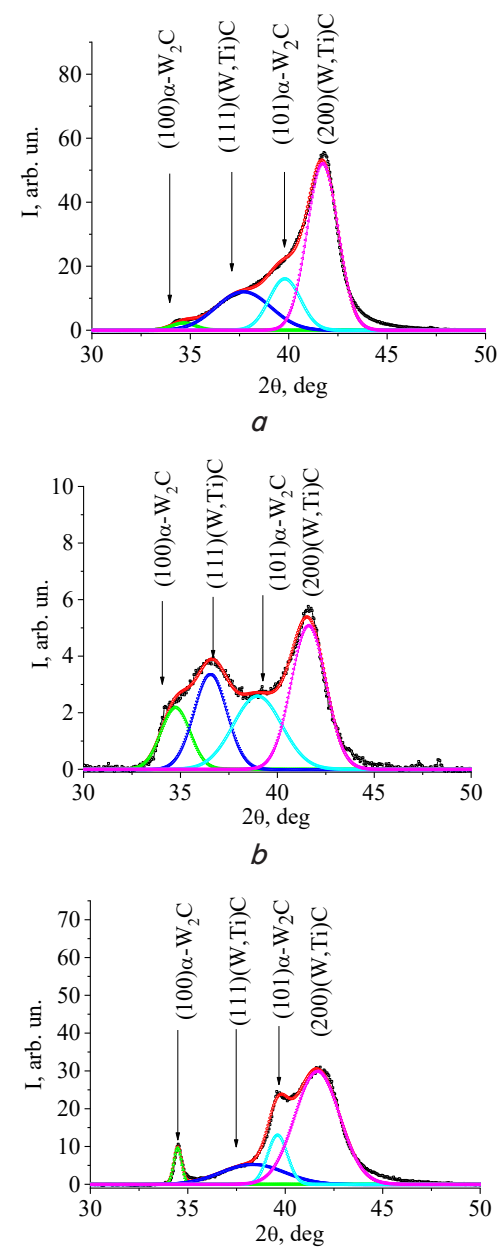

c

Fig. 7. The result of decomposition of complex diffraction profiles on the spectra of coatings: $a$-deposited at $T_{s}=700^{\circ} \mathrm{C}$ and a bias potential of $-50 \mathrm{~V}, b-$ deposited at $T_{s}=700{ }^{\circ} \mathrm{C}$ and a bias potential $-115 \mathrm{~V}, c-$ deposited at $T_{s}=950^{\circ} \mathrm{C}$

Thus, in contrast to the radiation factor leading to the fragmentation of grains of both phases, with an increase in the thermal factor (deposition temperature), the formation of a two-phase state is accompanied by different changes in the size of $(\mathrm{W}, \mathrm{Ti}) \mathrm{C}$ crystallites and $\alpha-\mathrm{W}_{2} \mathrm{C}$ constituents in the condensates.

\section{Discussion of the research results on the influence of thermal and radiation factors on the phase-structural state of condensates}

The need to use thermal and radiation factors to increase the adhesion of the coating to the substrate determines a number of features in the formation of coatings based on solid solutions. Moreover, the high rate of thermalization of particle energy in ion-plasma methods for producing coatings $[6,9,13]$ determines a wide range of formed structural states, including nonequilibrium phase states, as well as substantially supersaturated solid solutions. Both of these states are characteristic of coatings based on the WC-TiC quasibinary system.

It should be noted that in the temperature range of $80-$ $950{ }^{\circ} \mathrm{C}$ (used in the work) in the equilibrium state, tungsten carbide has a hexagonal crystal lattice. The cubic crystal lattice (structural type $\mathrm{NaCl}$ ) is characteristic only for the high-temperature (over $2000{ }^{\circ} \mathrm{C}$ ) region of the $\mathrm{W}$-C equilibrium diagram. Stabilization of the phase with a cubic lattice becomes possible in ion-plasma condensates at low temperature due to the high rate of thermalization of particles.

The supersaturation of the solid solution also reaches large values in comparison with the equilibrium state. For a phase with a cubic lattice in the $\mathrm{W}-\mathrm{Ti}-\mathrm{C}$ system, the limiting content of tungsten atoms is less than $75 \%$ (and not more than $90 \%$, as is achieved in condensates, Table 1).

From the obtained results it follows that the decomposition of a supersaturated solid solution with the formation of a 2-phase state can be achieved in two ways:

1) when using a high (more than $700{ }^{\circ} \mathrm{C}$ ) substrate temperature during deposition (Fig. 4, 7, c);

2) by applying a negative bias potential to the substrate (decay occurs even at a relatively small potential $-50 \mathrm{~V}$, Fig. 6, 7,a).

In the thermal method of decay activation, 2 methods were used: heating the substrate during deposition and high-temperature annealing of the coatings after their formation. The method of high-temperature annealing of coatings after their formation showed a relatively low efficiency of decay activation. Even at the highest annealing temperature of $1000{ }^{\circ} \mathrm{C}$ and holding for 2 hours, the percentage of release of the $\alpha-W_{2} C$ phase is much lower than during precipitation for 1 hour with $T_{s}=950{ }^{\circ} \mathrm{C}$. At a lower annealing temperature of $800^{\circ} \mathrm{C}$, no noticeable change in the phase-structural state is observed, and the change in the lattice period is apparently associated with relaxation of the initial compression stresses (Fig. 6, spectrum 4).

A feature of the influence of the thermal factor $\left(T_{s}\right)$ during the deposition of the coating revealed in the work is the enrichment of the coating with heavy $\mathrm{W}$ atoms and a decrease in the content of $\mathrm{Ti}$ atoms and carbon atoms with increasing $T_{s}$. It should be noted that a decrease in the relative content of carbon atoms should contribute to the formation of the $\alpha-\mathrm{W}_{2} \mathrm{C}$ phase (as phases with a lower carbon content). In this case, it is possible to adjust the phase ratio in the coating, which is difficult with the magnetron method in the case of using a two-phase target.

The supply of a bias potential also leads to the formation of a two-phase state. A feature of this state is the very small crystallite size. With an increase in the bias potential from $-50 \mathrm{~V}$ to $-115 \mathrm{~V}$, the average crystallite size decreases from $4.5 \mathrm{~nm}$ to $3.8 \mathrm{~nm}$ (Fig. 7, $a, b$ ).

It should be noted that the transformation $(\mathrm{W}, \mathrm{Ti}) \mathrm{C} \rightarrow$ $\rightarrow \alpha-W_{2} \mathrm{C}$ must pass through the stage of formation of stacking faults. This follows from the laws governing the transition of pure tungsten monocarbide $(\beta-\mathrm{WC})$ to the $\alpha-\mathrm{W}_{2} \mathrm{C}$ phase [6]. The difference between the system studied in this work is only the formation of $(\mathrm{W}, \mathrm{Ti}) \mathrm{C}$ solid solution based on a modification with a cubic lattice $\beta-\mathrm{WC}$. For the structural type of $\mathrm{NaCl}$ (to which the (W, Ti)C phase belongs), in the [111] direction there is an alternation of layers con- 
sisting of either only metal atoms or only carbon atoms. The determining factor in such a structure is the shift in the metal lattice. Fig. 8 shows a schematic view of such a conversion from the FCC to the hexagonal crystal lattice.

We note that, as was established in [6], in nanocrystallites of ion-plasma condensates based on tungsten carbide, the deformation of the crystal lattice upon conversion from cubic to hexagonal crystal lattice occurs with an invariant plane. This plane is the common plane of the boundaries of the two phases, which leads to the displacement of atoms in the direction of the shear vector (Fig. 8).

Thus, in this work, the possibility of creating a twophase nanocomposite was revealed. This was achieved by using the substrate temperature more than $700{ }^{\circ} \mathrm{C}$ during deposition, as well as by applying a negative mixing potential of $-50 \mathrm{~V}$ or more. This effect is achieved only with compositions with a low $\mathrm{TiC}$ content (in this work, this was achieved with a content of $10 \mathrm{~mol} . \% \mathrm{TiC}$ ). In this case, the state with the crystal lattice of the (W, Ti)C phase becomes unstable.

It should be noted that, in contrast to the metastable state of a supersaturated solid solution, the formation of a two-phase state (with different types of crystal lattices) effectively prevents the propagation of cracks in the coating material. This increases its strength and crack resistance. Therefore, the use of structural engineering methods in the work to create the corresponding twophase materials is the basis for increasing the strength and crack resistance of coatings of such systems. Therefore, it is planned to further develop research by conducting comparative mechanical tests of coatings and optimizing coatings by their composition.

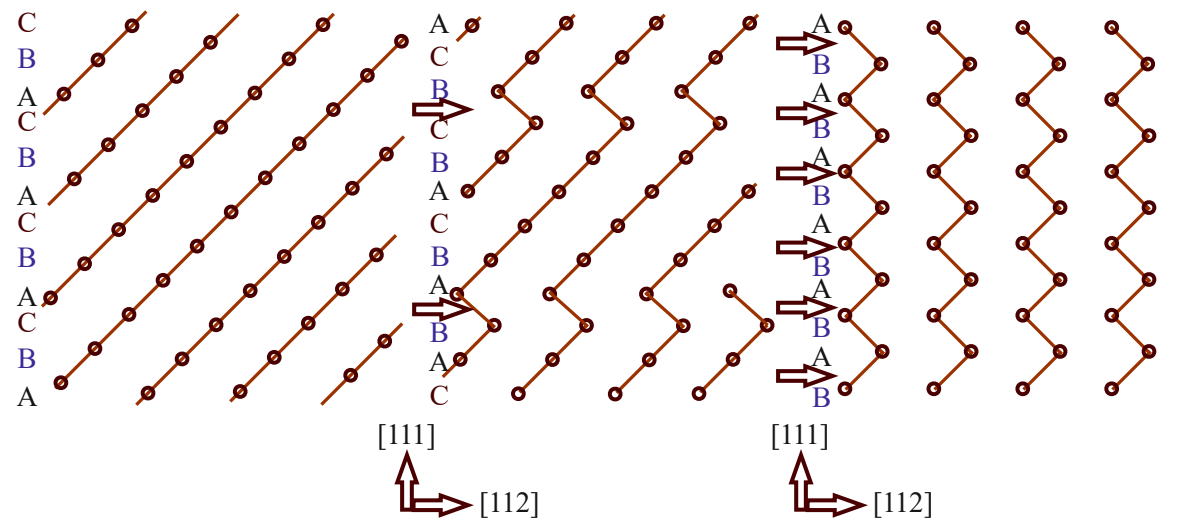
through the stage of formation of stacking faults

\section{Conclusions}

1. It was found that with an increase in the deposition temperature in the elemental composition of the coating, the relative content of heavy metal atoms $\mathrm{W}$ increases and the relative content of $\mathrm{Ti}$ and $\mathrm{C}$ atoms decreases. At the phase-structural level, this is manifested in the formation of a single-phase state of a supersaturated solid solution to $T_{s}=700{ }^{\circ} \mathrm{C}$. At higher $T_{s}$, the solid solution decomposes with the formation of a twophase state from (W, Ti) C and $\alpha-\mathrm{W}_{2} \mathrm{C}$ phases.

2. The use of high-temperature annealing of coatings after their formation showed a relatively low decay activation efficiency. At an annealing temperature of $800{ }^{\circ} \mathrm{C}$, a noticeable change in the phase-structural state is not observed. For the highest annealing temperature of $1000{ }^{\circ} \mathrm{C}$ and holding for 2 hours, the $\alpha-W_{2} C$ phase is released, however, the percentage of this phase is relatively low (about $15 \mathrm{vol}$ \%).

3. It was revealed that the supply of the bias potential leads to the formation of a two-phase state from (W, Ti)C and $\alpha-\mathrm{W}_{2} \mathrm{C}$ phases. A feature of this state is the very small crystallite size. With an increase in the bias potential from $-50 \mathrm{~V}$ to $-115 \mathrm{~V}$, the average crystallite size decreases from $4.5 \mathrm{~nm}$ to $3.8 \mathrm{~nm}$.

References

1. Morton, B. D., Wang, H., Fleming, R. A., Zou, M. (2011). Nanoscale Surface Engineering with Deformation-Resistant Core-Shell Nanostructures. Tribology Letters, 42 (1), 51-58. doi: https://doi.org/10.1007/s11249-011-9747-0

2. Bourebia, M., Laouar, L., Hamadache, H., Dominiak, S. (2016). Improvement of surface finish by ball burnishing: approach by fractal dimension. Surface Engineering, 33 (4), 255-262. doi: https://doi.org/10.1080/02670844.2016.1232778

3. Sobol', O. V., Andreev, A. A., Gorban', V. F. (2016). Structural Engineering of Vacuum-ARC Multiperiod Coatings. Metal Science and Heat Treatment, 58 (1-2), 37-39. doi: https://doi.org/10.1007/s11041-016-9961-3

4. Mayrhofer, P. H., Mitterer, C., Wen, J. G., Greene, J. E., Petrov, I. (2005). Self-organized nanocolumnar structure in superhard TiB2 thin films. Applied Physics Letters, 86 (13), 131909. doi: https://doi.org/10.1063/1.1887824

5. Sobol', O. V., Andreev, A. A., Gorban', V. F., Meylekhov, A. A., Postelnyk, H. O. (2016). Structural Engineering of the Vacuum Arc ZrN/CrN Multilayer Coatings. Journal of Nano- and Electronic Physics, 8 (1), 01042. doi: https://doi.org/10.21272/ jnep.8(1).01042

6. Sobol', O. V. (2016). Structural Engineering Vacuum-plasma Coatings Interstitial Phases. Journal of Nano- and Electronic Physics, 8 (2), 02024. doi: https://doi.org/10.21272/jnep.8(2).02024

7. Yu, D., Wang, C., Cheng, X., Zhang, F. (2009). Microstructure and properties of TiAlSiN coatings prepared by hybrid PVD technology. Thin Solid Films, 517 (17), 4950-4955. doi: https://doi.org/10.1016/j.tsf.2009.03.091

8. Jaroš, M., Musil, J., Čerstvý, R., Haviar, S. (2017). Effect of energy on structure, microstructure and mechanical properties of hard Ti(Al,V)Nx films prepared by magnetron sputtering. Surface and Coatings Technology, 332, 190-197. doi: https://doi.org/10.1016/ j.surfcoat.2017.06.074 
9. Musil, J., Kos, Š., Zenkin, S., Čiperová, Z., Javdošňák, D., Čerstvý, R. (2018). $\beta$ - (Me1, Me2) and MeNx films deposited by magnetron sputtering: Novel heterostructural alloy and compound films. Surface and Coatings Technology, 337, 75-81. doi: https://doi.org/10.1016/j.surfcoat.2017.12.057

10. Lackner, J., Waldhauser, W., Major, L., Kot, M. (2014). Tribology and Micromechanics of Chromium Nitride Based Multilayer Coatings on Soft and Hard Substrates. Coatings, 4 (1), 121-138. doi: https://doi.org/10.3390/coatings4010121

11. Sobol', O. V., Meilekhov, A. A. (2018). Conditions of Attaining a Superhard State at a Critical Thickness of Nanolayers in Multiperiodic Vacuum-Arc Plasma Deposited Nitride Coatings. Technical Physics Letters, 44 (1), 63-66. doi: https://doi.org/ $10.1134 / \mathrm{s} 1063785018010224$

12. Silva, F. J. G., Martinho, R. P., Alexandre, R. J. D., Baptista, A. P. M. (2012). Wear Resistance of TiAlSiN Thin Coatings. Journal of Nanoscience and Nanotechnology, 12 (12), 9094-9101. doi: https://doi.org/10.1166/jnn.2012.6760

13. Endrino, J. L., Palacín, S., Aguirre, M. H., Gutiérrez, A., Schäfers, F. (2007). Determination of the local environment of silicon and the microstructure of quaternary $\mathrm{CrAl}(\mathrm{Si}) \mathrm{N}$ films. Acta Materialia, 55 (6), 2129-2135. doi: https://doi.org/10.1016/ j.actamat.2006.11.014

14. Shizhi, L., Yulong, S., Hongrui, P. (1992). Ti-Si-N films prepared by plasma-enhanced chemical vapor deposition. Plasma Chemistry and Plasma Processing, 12 (3), 287-297. doi: https://doi.org/10.1007/bf01447027

15. Vepřek, S. (1999). The search for novel, superhard materials. Journal of Vacuum Science \& Technology A: Vacuum, Surfaces, and Films, 17 (5), 2401-2420. doi: https://doi.org/10.1116/1.581977

16. Veprek, S., Veprek-Heijman, M. G. J., Karvankova, P., Prochazka, J. (2005). Different approaches to superhard coatings and nanocomposites. Thin Solid Films, 476 (1), 1-29. doi: https://doi.org/10.1016/j.tsf.2004.10.053

17. Sobol, O. V., Postelnyk, A. A., Meylekhov, A. A., Andreev, A. A., Stolbovoy, V. A. (2017). Structural Engineering of the Multilayer Vacuum Arc Nitride Coatings Based on Ti, Cr, Mo and Zr. Journal of Nano- and Electronic Physics, 9 (3), 03003. doi: https://doi.org/ 10.21272/jnep.9(3).03003

18. Zhang, R. F., Veprek, S. (2006). On the spinodal nature of the phase segregation and formation of stable nanostructure in the TiSi-N system. Materials Science and Engineering: A, 424 (1-2), 128-137. doi: https://doi.org/10.1016/j.msea.2006.03.017

19. Sobol, O. V., Dub, S. N., Pogrebnjak, A. D., Mygushchenko, R. P., Postelnyk, A. A., Zvyagolsky, A. V., Tolmachova, G. N. (2018). The effect of low titanium content on the phase composition, structure, and mechanical properties of magnetron sputtered WB2-TiB2 films. Thin Solid Films, 662, 137-144. doi: https://doi.org/10.1016/j.tsf.2018.07.042

20. Euchner, H., Mayrhofer, P. H. (2015). Designing thin film materials - Ternary borides from first principles. Thin Solid Films, 583, 46-49. doi: https://doi.org/10.1016/j.tsf.2015.03.035

21. Li, D., Lin, X., Cheng, S., Dravid, V. P., Chung, Y., Wong, M., Sproul, W. D. (1996). Structure and hardness studies of CNx/TiN nanocomposite coatings. Applied Physics Letters, 68 (9), 1211-1213. doi: https://doi.org/10.1063/1.115972

22. Sobol', O. V., Meylekhov, A. A., Stolbovoy, V. A., Postelnyk, A. A. (2016). Structural Engineering Multiperiod Coating ZrN/MoN. Journal of Nano- and Electronic Physics, 8 (3), 03039. doi: https://doi.org/10.21272/jnep.8(3).03039

23. Krause-Rehberg, R., Pogrebnyak, A. D., Borisyuk, V. N., Kaverin, M. V., Ponomarev, A. G., Bilokur, M. A. et. al. (2013). Analysis of local regions near interfaces in nanostructured multicomponent (Ti-Zr-Hf-V-Nb)N coatings produced by the cathodic-arc-vapordeposition from an arc of an evaporating cathode. The Physics of Metals and Metallography, 114 (8), 672-680. doi: https://doi.org/ 10.1134/s0031918x13080061

24. Tjong, S. C., Chen, H. (2004). Nanocrystalline materials and coatings. Materials Science and Engineering: R: Reports, 45 (1-2), 1-88. doi: https://doi.org/10.1016/j.mser.2004.07.001

25. Sobol', O. V., Andreev, A. A., Gorban', V. F., Stolbovoy, V. A., Melekhov, A. A., Postelnyk, A. A. (2016). Possibilities of structural engineering in multilayer vacuum-arc $\mathrm{ZrN} / \mathrm{CrN}$ coatings by varying the nanolayer thickness and application of a bias potential. Technical Physics, 61 (7), 1060-1063. doi: https://doi.org/10.1134/s1063784216070252

26. Geng, Z., Liu, Y., Zhang, H. (2018). Tribological properties of electrodeposited Ni-ZrO2 nanocomposite coatings on copperplate of crystallizer. Surface Engineering, 35 (10), 919-926. doi: https://doi.org/10.1080/02670844.2018.1482675

27. Ghadami, F., Zakeri, A., Aghdam, A. S. R., Tahmasebi, R. (2019). Structural characteristics and high-temperature oxidation behavior of HVOF sprayed nano-CeO2 reinforced NiCoCrAlY nanocomposite coatings. Surface and Coatings Technology, 373, 7-16. doi: https://doi.org/10.1016/j.surfcoat.2019.05.062

28. Chen, Z., Qiao, L., Hillairet, J., Song, Y., Turq, V., Wang, P. et. al. (2019). Development and characterization of magnetron sputtered self-lubricating Au-Ni/a-C nano-composite coating on $\mathrm{CuCrZr}$ alloy substrate. Applied Surface Science, 492, 540-549. doi: https://doi.org/10.1016/j.apsusc.2019.06.240

29. Ivashchenko, V. I., Dub, S. N., Scrynskii, P. L., Pogrebnjak, A. D., Sobol', O. V., Tolmacheva, G. N. et. al. (2016). Nb-Al-N thin films: Structural transition from nanocrystalline solid solution nc-(Nb,Al)N into nanocomposite nc-(Nb, Al)N/a-AlN. Journal of Superhard Materials, 38 (2), 103-113. doi: https://doi.org/10.3103/s1063457616020040

30. Banerjee, P., Bagchi, B. (2018). Effects of metastable phases on surface tension, nucleation, and the disappearance of polymorphs. The Journal of Chemical Physics, 149 (21), 214704. doi: https://doi.org/10.1063/1.5054151 
31. Sobol', O. V. (2011). Control of the structure and stress state of thin films and coatings in the process of their preparation by ionplasma methods. Physics of the Solid State, 53 (7), 1464-1473. doi: https://doi.org/10.1134/s1063783411070274

32. Rempel, A. A., Gusev, A. I. (2000). Preparation of disordered and ordered highly nonstoichiometric carbides and evaluation of their homogeneity. Physics of the Solid State, 42 (7), 1280-1286. doi: https://doi.org/10.1134/1.1131377

33. Jansson, U., Lewin, E. (2013). Sputter deposition of transition-metal carbide films - A critical review from a chemical perspective. Thin Solid Films, 536, 1-24. doi: https://doi.org/10.1016/j.tsf.2013.02.019

34. Zhang, Y., Li, J., Zhou, L., Xiang, S. (2002). A theoretical study on the chemical bonding of 3d-transition-metal carbides. Solid State Communications, 121 (8), 411-416. doi: https://doi.org/10.1016/s0038-1098(02)00034-0

35. Sobol', O. V., Shovkoplyas, O. A. (2013). On advantages of X-ray schemes with orthogonal diffraction vectors for studying the structural state of ion-plasma coatings. Technical Physics Letters, 39 (6), 536-539. doi: https://doi.org/10.1134/s1063785013060126

36. Smith, D. K., Jenkins, R. (1996). The Powder Diffraction file: Past, present, and future. Journal of Research of the National Institute of Standards and Technology, 101 (3), 259. doi: https://doi.org/10.6028/jres.101.027

37. Bushroa, A. R., Rahbari, R. G., Masjuki, H. H., Muhamad, M. R. (2012). Approximation of crystallite size and microstrain via XRD line broadening analysis in TiSiN thin films. Vacuum, 86 (8), 1107-1112. doi: https://doi.org/10.1016/j.vacuum.2011.10.011

38. Veprek, S., Veprek-Heijman, M. J. G. (2008). Industrial applications of superhard nanocomposite coatings. Surface and Coatings Technology, 202 (21), 5063-5073. doi: https://doi.org/10.1016/j.surfcoat.2008.05.038

39. Musil, J., Daniel, R., Zeman, P., Takai, O. (2005). Structure and properties of magnetron sputtered Zr-Si-N films with a high ( $\geq 25$ at.\%) Si content. Thin Solid Films, 478 (1-2), 238-247. doi: https://doi.org/10.1016/j.tsf.2004.11.190

40. Thornton, J. A. (1974). Influence of apparatus geometry and deposition conditions on the structure and topography of thick sputtered coatings. Journal of Vacuum Science and Technology, 11 (4), 666-670. doi: https://doi.org/10.1116/1.1312732 